\title{
Corruption scandals in six Asian countries: a comparative analysis
}

\author{
Jon S.T. Quah
Anti-Corruption Consultant, \\ Jon S.T. Quah
Anti-Corruption Consultant, Singapore
}

Corruption

scandals in

Asian

countries

\begin{abstract}
Purpose - The purpose of this paper is to compare and evaluate how the governments in six Asian countries have dealt with selected grand corruption scandals.

Design/methodology/approach - This paper is based on the comparative analysis of 11 corruption scandals examined in the six articles on India, Japan, Macau, Malaysia, Philippines and Singapore included in this special issue of Public Administration and Policy.

Findings - The responses of the governments in the six countries depend on the strength of their political will in combating corruption. The responses of the governments in Malaysia, Philippines, India and Japan reflect their weak political will in combating corruption and lack of accountability of the corrupt offenders. By contrast, the strong political will of the governments in Singapore and Macau is reflected in the investigation and punishment of the corrupt offenders without any cover-up of the scandals.

Originality/value - The findings would be of interest to scholars, policymakers and anti-corruption practitioners and activists.
\end{abstract}

Keywords India, Japan, Macau, Malaysia, Philippines, Singapore

Paper type Research paper

\section{Research on corruption scandals in Asian countries}

King (1986, p. 174), in his pioneering study of political scandals, contends that "political scandals are worth studying for the light they can throw on a country's political culture and political system." However, the comparative study of political scandals is still in its infancy. Research on corruption scandals in Japan has focussed on the Teijin scandal (Mitchell, 2002), Lockheed scandal (Dixon, 1977; Kan'ichi, 1976; Kitazawa, 1976; MacDougall, 1988), Recruit scandal (Kearns, 1990; Yayama, 1990) and policy failure scandals (Carlson, 2017; Carlson and Reed, 2018a). In India, research was conducted on the Bofors scandal (Oza, 1997), Tehelka scandal (Trehan, 2009) and Coalgate scandal (Parakh, 2014). In Malaysia, research was done on the Bumiputra Malaysia Finance scandal (Lim, 1986; Milne, 1987) and the 1Malaysia Development Berhad (1MDB) scandal (Brown, 2018; Case, 2017; Gunasegaram, 2018; Wright and Hope, 2019) and a comparison of both scandals (Teh, 2018). The major studies on corruption scandals in Hong Kong are done by Downey (1975), Lethbridge (1985) and Scott (2014).

An extensive literature on corruption in China exists (Meng, 2013; Quah, 2013; Pesqué-Cela, 2018) but limited research has focussed on corruption scandals. China's political leaders have used corruption allegations to eliminate their political opponents during the past two decades by linking them with corruption scandals (Ho and Huang, 2013, p. 4). Prominent examples include the purging of Chen Xitong by Jiang Zemin, Chen Liangyu by Hu Jintao and Bo Xilai and Zhou Yongkang by Xi Jinping. Amongst these four scandals, Bo's role is

(C) Jon S.T. Quah. Published in Public Administration and Policy. Published by Emerald Publishing Limited. This article is published under the Creative Commons Attribution (CC BY 4.0) license. Anyone may reproduce, distribute, translate and create derivative works of this article (for both commercial and non-commercial purposes), subject to full attribution to the original publication and authors. The full terms of this license may be seen at http://creativecommons.org/licences/by/4.0/legalcode

The author is grateful to Professors Peter Fong, Ian Scott and Daniel Zirker for their useful comments on an earlier version of this paper.

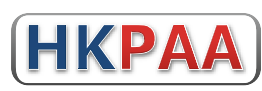

Received 22 January 2020 Revised 26 February 2020 Accepted 28 February 2020

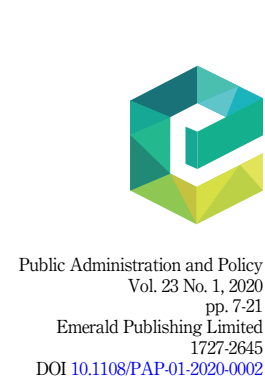


PAP

23,1

8

analysed by Garnault (2012) and Lee (2018) and Zhou's corrupt network is unravelled by Zhu (2017).

The Global Corruption Report 2004 identified three Asian leaders: President Suharto of Indonesia (ranked first), Presidents Ferdinand Marcos (ranked second) and Joseph Estrada (ranked 10th) of the Philippines, amongst the 10 most corrupt world leaders (Transparency International, 2004, p. 13). Corruption was institutionalised during Suharto's administration (1966-1998) and his family members benefitted from their monopoly of the import, manufacture and distribution of many products. In May 1999, Time magazine published a special report exposing the Suharto family's US\$15 billion fortune (Colmey and Liebhold, 1999, pp. 15-29). The most comprehensive study of the corruption of President Marcos and his cronies was conducted by Aquino (1999). President Estrada's "unexplained wealth" and "propensity for acquiring real estate" was investigated by Coronel (2000).

This special issue of Public Administration and Policy contributes to the growing literature by analysing the 11 grand corruption scandals selected in India by Krishna Tummala, Japan by Matthew Carlson, Macau by Sonny Lo, Malaysia by David Jones, Philippines by Eric Batalla and Singapore by Jon Quah. This article provides a comparative analysis of how the six governments have dealt with these scandals and identifies the three lessons for combating corruption in other countries.

As corruption occurs in the public and private sectors in Asian countries, it refers to "the misuse of public or private power, office or authority for private benefit - through bribery, extortion, influence peddling, nepotism, fraud, speed money or embezzlement" (Quah, 2011, p. 10). Following this definition, it is necessary to distinguish between grand and petty corruption. Grand corruption refers to corrupt acts committed by political leaders and senior civil servants and usually involves "large, international bribes and 'hidden' overseas bank accounts" (Pope, 2000, p. xix). By contrast, petty corruption involves poorly paid low-ranking civil servants demanding bribes from those they serve to expedite their applications or perform other favours as a coping strategy to support their families.

Thompson distinguishes between sex scandals involving the transgression of sexual norms and codes; financial scandals infringing rules and conventions governing the use of economic resources; and power scandals infringing rules governing the use of political power. However, such corrupt acts only become scandalous when they are disclosed to nonparticipants, seriously infringe rules, conventions or laws concerning the proper exercise of public duties, and are condemned by the public (Thompson, 2000, pp. 120-122, 29-30). Finally, Lowi (1988, p. viii) distinguishes the substantive scandal or the "breach of an actual norm" from the procedural scandal, which involves the concealment of the substantive misconduct. This article adopts the definition of scandal by West $(2006$, p. 6) as "an event in which the public revelation of an alleged private breach of a law or a norm results in significant social disapproval or debate and, usually, reputational damage." Using West's definition, a corruption scandal refers to the public exposure of corruption offences that result in social disapproval and reputational damage of the offenders.

\section{Grand corruption scandals in six Asian countries}

The 1MDB scandal, which is analysed in Jones' article, is "the world's biggest financial scandal" and "largest kleptocracy case" in US history because the US Department of Justice believed that more than US\$4.5 billion was stolen from 1MDB (Ramesh, 2016). When the police raided the Najib family's apartments on 16-17 May 2018 in Kuala Lumpur, they confiscated US $\$ 274$ million worth of luxury items, including 567 handbags, 423 watches, 12,000 pieces of jewellery and US\$28 million in cash (Wright and Hope, 2019, p. 406).

Batalla's article focusses on the approval of two mega infrastructure projects in the Philippines by two presidents without competitive public bidding. The first scandal involved 
Herminio Disini, President Marcos' golfing buddy and relative of Imelda, who received a substantial commission from Westinghouse Electric Company for brokering a meeting to obtain Marcos' approval to build the Bataan Nuclear Power Plant (BNPP) in June 1976 without following the proper procurement guidelines (Beaver, 1994). The original project cost of US $\$ 1.1$ billion increased to US $\$ 2.1$ billion when the BNPP was completed because of the additional safety requirements arising from the Three Mile Island accident in Pennsylvania in March 1979, interest charges, inflation and foreign exchange losses. Disini was charged by the Office of the Ombudsman (OMB) with corruption in June 2004 and ordered by the AntiGraft Court in April 2012 to return US\$50 million in commission but he died in June 2014 without doing so. The Anti-Graft Court dismissed the case against Marcos as there was insufficient evidence that he had received any commission from the Westinghouse deal (Mendoza et al., 2016, p. 9).

In the second scandal, President Gloria Macapagal-Arroyo approved on 21 April 2007 the proposal of the Zhongxing Telecommunications Equipment (ZTE) Company from China to develop the National Broadband Network (NBN) project using US\$329 million in loans from China's Export-Import Bank. On 27 April, journalist Jarius Bondoc revealed that an unnamed Commission of Elections (Comelec) official, who was later identified as its chairman Benjamin Abalos, was involved in brokering the over-priced NBN project. After the Senate Blue Ribbon Committee investigated the NBN deal on 18 September 2007, President Arroyo suspended the NBN project on 22 September and cancelled it during her state visit to China on 2nd October (Llanto and Chavez, 2008).

Lo compares the corruption scandals involving two senior public officials in Macau. First, Ao Man-long, the Secretary for Public Works and Transport for the Macau Special Administrative Region (SAR) from 1999 to 2006 was arrested for bribery by the Macau Commission Against Corruption (CAC) on 8 December 2006. In January 2008, he was found guilty of 40 counts of bribery, 13 counts of money laundering and two counts of abuse of power and sentenced initially to 27 years of imprisonment and fined 240,000 patacas (US\$29,838). In May 2012, Ao was found guilty of accepting bribes of 31.9 million patacas (US\$3.9 million) and given a final jail sentence of 29 years (Meneses, 2019). Second, Ho Chiomeng, Macau's Prosecutor-General from 1999 to 2014, was arrested on 26 February 2016 and charged with 1,536 offences, including embezzlement, fraud, abuse of power, money laundering, unjustified economic wealth and inaccurately reporting his income. He was sentenced in July 2017 by the Court of Final Appeal to 21 years' imprisonment for his crimes and fined 18 million patacas (US $\$ 2.2$ million) for benefitting from illegally awarding contracts worth 167 million patacas (US\$20 million) (Plataforma Macau, 2018).

Quah focusses on two corruption scandals in Singapore. The first scandal involved Teh Cheang Wan, the Minister for National Development, who was questioned by the Corrupt Practices Investigation Bureau (CPIB) on 2 December 1986 regarding two complaints that he had accepted bribes of $\mathrm{S} \$ 1$ million from a building contractor. However, he committed suicide on 14 December before he could be prosecuted in court. The second scandal involved Edwin Yeo, an Assistant Director of the CPIB, who was charged in July 2013 with misappropriating S\$1.76 million (US\$1.41 million) from 2008 to 2012 . He was found guilty and sentenced to 10 years' imprisonment on 20 February 2014 for criminal breach of trust as a public servant and for forgery (Chong, 2014, p. A1).

The grand corruption scandals in Japan analysed by Carlson did not involve bribery or embezzlement but sontaku or the granting of special treatment by officials for those projects associated with prominent persons. Yasunori Kagoike, Head Director of Moritomo Gakuen School, claimed in 2017 that his application to purchase state-owned land at a huge discount to expand his school was approved earlier by the Ministry of Finance officials because they assumed that this was what Prime Minister Shinzo Abe and his wife, who was a friend of Kagoike's wife and an honorary principal of the school, wanted. Abe and his wife denied any
Corruption scandals in Asian countries 
PAP

23,1

involvement in influencing Kagoike's application. The Ministry of Finance and local administrators involved in the sale of land said that they had discarded key documents following the laws on storing and handling of government documents. The Osaka prefectural government revealed that Kagoike had inflated the land costs to obtain a larger subsidy but used a lower estimate to show that Moritomo could afford to buy the land. Consequently, the sale of the land and permit was revoked, and Kagoike returned the subsidy and withdrew his application. Kagoike and his wife were arrested and put on trial for subsidy fraud. They were found guilty of receiving $¥ 56.4$ million (US\$512,000) in central government subsidies illegally and sentenced to five and three years' imprisonment, respectively, in February 2020 (Japan Times, 2020).

The second Japanese scandal also involved Prime Minister Abe, who was accused by opposition political leaders for favouring Kotaro Kake's application for a special deregulation project in Imabari, Ehime Prefecture (Yoshida, 2018). Abe met Kake while studying in the United States, and they became close friends and played golf regularly. After the government approved Kake's application to build a new faculty of veterinary medicine in the Okayama University of Science, which is part of Kake Gakuen, the opposition political leaders repeatedly asked Abe, in spite of his many denials, whether he had favoured Kake and discussed his application on the golf course (Sim, 2017). The scandal was exposed by the publication of leaked internal Ministry of Education documents which revealed that following Abe's intention to expedite approval for the project, the government favoured Kake Gakuen before its application was reviewed by the officials. A former ministry bureaucrat, Kihei Maekawa, confirmed that Abe's office had intervened to approve Kake Gakuen's application by changing the requirements to facilitate its selection over another competing university. The government denied the accusations of Maekawa and other critics but could not provide evidence to substantiate its claims. Nevertheless, the Minister for Education approved the establishment of the new veterinary school in April 2019.

The two scandals in India analysed by Tummala focus on constitutional corruption, which he defines as using the constitution for corrupt purposes to advance personal or partisan interests. First, the original Rafale fighter jet deal negotiated in 2007 by Prime Minister Manmohan Singh's United Progressive Alliance (UPA) government involved the purchase of 126 fighter jets from the French company Dassault Aviation with Hindustan Aeronautics Limited (HAL) in India as the technical partner. However, the deal became controversial because negotiations were delayed and the contract was not signed before the UPA government lost its majority in the April-May 2014 general election. During his official visit to France in April 2015, Prime Minister Narendra Modi announced that India would purchase 36 Rafale jets at a cost of Rs 580 billion (US\$8.1 billion) and replace HAL with Reliance Defence as the Indian offset partner (IOP). Consequently, this new deal was criticised by the opposition political parties for being over-priced, and demonstrated the abuse of authority, cronyism and flouting of standard procurement procedures by Modi's government (Hilotin, 2019).

Several litigants filed petitions in 2018 under Article 32 of the Constitution to challenge the new deal because of these questions on perceived procedural irregularities: (1) Did Prime Minister Modi make the deal without the approval of the Cabinet Committee on Security? (2) Was Reliance Defence made Dassault Aviation's IOP without the Defence Minister's approval, as required by the Defence Offset Guidelines, and was HAL, the previously proposed IOP, improperly removed? (3) Does the intergovernmental deal between India and France allow the Central government to violate the Comptroller and Auditor-General's (Duties, Powers and Conditions of Service) Act without disclosing the details of the deal? (4) Is the deal over-priced as the price of each aircraft in the second deal is nearly twice the price of each aircraft in the first deal? On 14 December 2018, the Supreme Court dismissed the plea for a court monitored investigation because it did not find any irregularity in the decision- 
making process, pricing or selection of an offset partner on the basis of the evidence provided by the State in sealed covers (Supreme Court Observer, 2019).

The second controversy concerns Article 370 of the Constitution of India, which granted special autonomy to the State of Jammu and Kashmir (J\&K) in October 1949, and Article 35A, which was added in 1954 to empower the provision of special rights and privileges in property ownership, education and jobs to its permanent residents. As many Muslims in J\&K resented heavy-handed rule from New Delhi, there has been an insurgency by Muslim separatists since 1989. As Prime Minister Modi and his Bharatiya Janata Party (BJP) had long opposed Article 370, they included its revocation in the BJP's 2019 election manifesto to ensure the integration of J\&K with the rest of India. Consequently, when the BJP won a landslide victory in the April-May 2019 general election, the government fulfilled its electoral pledge on 5 August 2019 by revoking Article 370 and dividing J\&K into the Union Territories of Ladakh (without a legislature) and Jammu and Kashmir (with a legislature). The government's decision to revoke Article 370 is controversial as Subhash Kashyap, a constitutional expert, said that the decision was "constitutionally sound" and without any "legal and constitutional fault." On the other hand, another constitutional expert, A.G. Noorani, disagreed because the revoking of Article 370 was "an illegal decision, akin to committing fraud" and could be challenged in the Supreme Court. However, as J\&K is an emotive issue with many Indians, the opposition political parties are cautious in challenging the government's decision to avoid being accused of being anti-India (BBC News, 2019).

\section{Globalization of corruption}

The digital revolution and emergence of "an electronically networked international financial system" increase the opportunities for corruption and the difficulty in controlling it because the globalization of electronic communications has facilitated the transfer of money across borders and money laundering involving many countries (Glynn et al., 1997, pp. 12-15). The $1 \mathrm{MDB}$ scandal in Malaysia illustrates clearly the serious consequences when the strict regulations preventing money laundering are not enforced by government officials and banks. At a press conference on 20 July 2016, the US Attorney-General Loretta Lynch announced that the Department of Justice had filed a complaint to forfeit and recover more than US $\$ 1$ billion in assets from the international conspiracy that laundered stolen funds from 1MDB from 2009 to 2015 through "opaque transactions and fraudulent shell companies" with bank accounts in the British Virgin Islands, Seychelles, Luxembourg, Singapore, Switzerland and the United States. The stolen funds were used by Jho Low, the alleged mastermind behind the money-laundering scheme, to purchase various assets for his relatives and associates, including luxury real estate in New York and Los Angeles, expensive artwork by Van Gogh and Monet, a US\$260 million superyacht, and a US\$35 million Bombardier Global 5000 business jet, and to invest more than US\$100 million to finance the 2013 film, The Wolf of Wall Street (Gabriel, 2018, pp. 69-70).

The Financial Action Task Force (FATF) is an intergovernmental organisation that was established in July 1989 to examine and develop measures for combating money laundering (FATF, 2019). To prevent money laundering, member countries should ensure that financial institution secrecy laws do not hinder the implementation of its recommendations. As Malaysia is a FATF member it should have adhered to the FATF's standards and recommendations. If Malaysia had followed these recommendations, the 1MDB scandal could have been prevented. According to Gabriel (2018, p. 74):

The 1MDB swindle would not have happened had [the] basic principles of public and corporate governance been followed, to include the use of proper checks on how 1MDB's funds were being
Corruption scandals in Asian countries 
PAP

23,1

handled. Such checks do exist in Malaysia. ... But 1MDB was exempted from all such controls, and no corrective measures were taken despite repeated signs of abuse.

By contrast, the two corruption scandals in the Philippines did not involve money laundering but bribery of senior government officials by US and Chinese companies to obtain the president's approval of two infrastructure projects without competitive public bidding. Macau's two senior public officials, Ao and Ho, were found guilty of embezzlement and money laundering but the amounts involved pale in comparison with the huge sums embezzled and laundered in the $1 \mathrm{MDB}$ scandal. The two corruption scandals in India demonstrate the impact of globalization in the sale of Rafale jet fighters from France to India and the BJP's revocation of Article 370 which divided J\&K into Ladakh and Jammu-Kashmir. The offences committed by Teh and Yeo in Singapore were bribery and embezzlement with no evidence of money laundering. Finally, the sontaku scandals in Japan focussed on the granting of special treatment by bureaucrats to approve the applications of projects of friends of Prime Minister Abe and his wife, and their subsequent attempts to conceal Abe's intervention.

\section{Governments' responses to corruption scandals}

The responses of the governments in the six countries to the selected grand corruption scandals depend on the strength of their political will and capacity to minimise corruption. Political will refers to the sustained commitment of political leaders to implement anticorruption policies and programmes to address the causes of corruption in their country (Quah, 2017, p. 64). When corruption scandals involving political leaders or senior civil servants are exposed by the investigation of corruption complaints by the anti-corruption agency (ACA), journalists or whistle-blowers, the government can either cover-up the scandals or investigate the offences impartially and punish the guilty offenders.

The 1MDB scandal in Malaysia was first exposed in March 2013 by the Malaysian on-line business newspaper, KINIBIZ, which published a series of articles on bond mispricing, overpayment for energy assets and other questionable deals (Gunasegaram, 2018, p. 14). On 28 February 2015, British journalist, Clare Rewcastle Brown, revealed on her website Sarawak Report that nearly US\$700 million had disappeared from the 1MDB joint venture and transferred to offshore companies and Swiss bank accounts (Brown, 2018, p. 191). The Wall Street Journal reported on 2 July 2015 that Prime Minister Najib Rajak had received US\$681 million in his private bank accounts in March 2013 (Wright and Hope, 2019, pp. 341-342).

Prime Minister Najib covered up the 1MDB scandal by removing from office the Deputy Prime Minister, four ministers, the Attorney-General and some junior officials during 20152016 to prevent them from revealing evidence of corruption or convening a public inquiry. The government also hampered investigations by withholding documents and computer files and influencing the investigators in the National Audit Department and the Malaysian AntiCorruption Commission (MACC) to alter their findings or abandon their investigations (Latiff and Ananthalakshmi, 2018). The procedural scandal or attempts by the government to conceal the $1 \mathrm{MDB}$ scandal enabled the opposition parties to criticise the $1 \mathrm{MDB}$ investment policies and increase public suspicions of malpractices in its financial dealings. The adverse publicity following the exposure of the $1 \mathrm{MDB}$ scandal angered many Malaysians and contributed to the defeat of Najib's government in the May 2018 general election (Weiss, 2019, pp. 144-145). By contrast, the new Pakatan Harapan government led by Prime Minister Mahathir Mohamad reconvened the special task force to revive the investigations into the $1 \mathrm{MDB}$ scandal, beginning with the arrests by MACC officers of Najib on 3 July and his wife on 3 October 2018 (Star Online, 2018). Najib's trial began in April 2019 and is still ongoing (Hassan, 2019, p. A9).

The contract for the BNPP project in the Philippines was signed by the National Power Corporation and Westinghouse Electric Company in February 1976 after two years of 
negotiations. General Electric and Westinghouse had competed for the BNPP contract. Unlike General Electric, which submitted a formal proposal, Westinghouse relied on Disini's connections with President Marcos to secure the contract without following the proper bidding process (Mendoza et al., 2016, p. 10). Disini's brokering of the deal for Westinghouse was exposed by reports in the Washington Post and New York Times in 1977-1978 and resulted in public controversy and resistance to the BNPP project because of the increased project cost of US\$2.1 billion and widespread public fears of a nuclear fallout after the March 1979 Three Mile Island accident (Mathews and Wideman, 1977, 1978; Butterfield, 1978). The Presidential Commission on Good Government (PCGG), which was established by President Corazon Aquino in 1986 to retrieve the money stolen by the Marcos family and its cronies, charged Disini in 1990 with corrupt practices for brokering the Westinghouse deal but the OMB dismissed the case against Disini in 1992 because of insufficient evidence. In June 2004, the OMB charged Disini for corrupting public officials but counter motions filed by him delayed action until April 2012, when the Anti-Graft Court ordered Disini to return the US\$50 million of commission from the BNPP deal but it dismissed the case against Marcos as there was inadequate evidence to prove that he had received the commission. In September 2013, the Supreme Court affirmed the Anti-Graft Court's decision requiring Disini to return the commission but he died in June 2014 without doing so. In short, no one was prosecuted for the corruption behind the BNPP project after 24 years of investigation and prosecution (Mendoza et al., 2016, pp. 9, 13-14).

The NBN-ZTE deal was controversial because investigations by the Senate Blue Ribbon Committee (SBRC) revealed unethical behaviour by the two groups competing for it. The ZTE group was supported by senior government officials and First Gentleman Mike Arroyo, the husband of President Arroyo. The other group was led by Jose de Venecia III, son of the House Speaker, Jose de Venecia, both of whom testified before the SBRC that top government officials had received commissions from ZTE and Mike Arroyo told them to withdraw from the project (Republic of the Philippines Senate, 2009, p. 1). After Comelec chairman Abalos was exposed for brokering the NBN-ZTE deal for ZTE in August 2007, the SBRC began investigating the deal on 18 September 2007 and President Arroyo suspended it on 22 September and cancelled it on 2 October during her state visit to China (Llanto and Chavez, 2008). The Arroyo government minimised the scandal's impact by transferring those officials involved in the deal (Republic of the Philippines Senate, 2009, pp. 32, 57). Abalos and Mike Arroyo were accused of receiving commissions for brokering the NBN-ZTE deal but there was insufficient evidence to prosecute them. Like the BNPP project, no one was prosecuted for brokering the NBN-ZTE deal as the Anti-Graft Court decided on 25 August 2016 that the prosecution failed to provide sufficient evidence for its charges against President Arroyo and her husband, Abalos, and Secretary Leandro Mendoza, who had signed the NBN-ZTE contract, and dismissed all the graft charges against them (Republic of the Philippines Sandiganbayan, 2016, pp. 29-31).

As the sontaku scandals in Japan involved Prime Minister Abe and his wife using their influence to expedite the applications of their friends, the officials from the Ministries of Finance and Education attempted to conceal their involvement to protect them from embarrassment. Abe's wife, Akie, was a friend of Junko, the wife of Moritomo Gakuen's Head Director, Kagoike, and was supportive of the school's mission to instil patriotism amongst its students (Carlson and Reed, 2018b). Akie's position as an honorary principal of the proposed elementary school was listed on the Moritomo Gakuen's website and publicised by the media. This revelation led to public scrutiny of the circumstances behind the approval of Moritomo's purchase of state-owned land. Abe forcefully denied any involvement in the land purchase and Kagoike's claim that he had donated one million yen to the school through Akie (Soble, 2017, p. 6). The Ministry of Finance officials initially favoured Kagoike's application as they assumed that their approval would please Abe and Akie. However, the public exposure of the
Corruption scandals in Asian countries 
school's plans embarrassed the Abe administration and the Asahi Shimbun revealed in March 2018 that the bureaucrats involved concealed their misconduct by altering 14 documents, including any embarrassing references to Abe and his wife, in February 2017. The suicide of Akagi, a local finance ministry official in Osaka, on 7 March 2018 exacerbated the scandal because he left a note admitting that he had altered the land records on the instructions of his superiors at the Ministry of Finance in Tokyo (Sim, 2020). Consequently, Nobuhisa Sagawa, Head of the Ministry's Financial Bureau, resigned on 9 March 2018 and an internal probe revealed that its officials had made about 200 alterations to documents (Sim, 2018). The Finance Minister apologised for the alterations and offered to reduce his salary and those of the 20 officials responsible as punishment but they were not punished for altering the documents.

A similar pattern of behaviour was observed in the Ministry of Education officials' expedited review and approval of Kake's application because of his friendship with Prime Minister Abe. The Ministry's top official, Kihei Maekawa, resigned to take responsibility for his ministry's actions but he later confirmed that the leaked documents from his ministry were authentic and indicated that his colleagues had favoured Kake's application (Osaki, 2017). However, apart from Maekawa's resignation, no other official was punished and the Ministry of Education approved Kake's application to establish his veterinary school in April 2019. Even though there was no evidence that Abe and his wife had directed the officials in the Ministries of Finance and Education to favour and expedite the applications of their friends, the attempts by the bureaucrats to alter the documents to conceal their involvement and protect them from embarrassment had eroded public support for the Abe administration (Osaki, 2017).

The corruption scandals in India occurred after Prime Minister Modi's BJP won the 2014 and 2019 general elections. The April 2015 announcement of the purchase of 36 Rafale jets from France at a much higher cost and different technical partner in India by Prime Minister Modi resulted in the opposition political parties criticising him for abuse of authority, cronyism and violation of the standard procurement procedures (Hilotin, 2019). Consequently, in 2018, several litigants filed petitions according to Article 32 of the Constitution to challenge the procedural irregularities of the new deal. However, the Supreme Court dismissed the plea for a court monitored investigation on 14 December 2018 as there were no irregularities in the decision-making process, pricing or selection of the technical partner (Supreme Court Observer, 2019). Similarly, on 5 August 2019, two and a half months after winning the April-May 2019 general election, Modi's government kept its electoral promise by revoking Article 370 and divided J\&K into Ladakh and Jammu-Kashmir. Even though the revocation of Article 370 is controversial and criticised by the opposition political parties, there has been no serious challenge so far to the government's decision.

Tummala contends in his article that the two scandals constitute serious threats to constitutional democracy in India because of the absence of consultation and transparency in decision-making. Modi decided on the purchase of the Rafale jet fighters unilaterally without consulting parliament and refused to answer questions concerning the new deal. Similarly, he revoked Article 370 without consulting the leaders and population in J\&K. The controversial $\mathrm{J} \& \mathrm{~K}$ decision is not surprising as the BJP had included it in its election manifestos for many years but Tummala questions the need for secrecy regarding the purchase of the Rafale jet fighters and Modi's refusal to defend his decision.

Unlike the MACC, which was ineffective in investigating the 1MDB scandal in Malaysia, and the OMB, which failed to prosecute the offenders in the BNPP and NBN-ZTE scandals in the Philippines, the CAC in Macau and the CPIB and Commercial Affairs Department (CAD) in Singapore were more effective in dealing with the four scandals. Macau CAC's investigation of Ao's and Ho's multiple offences resulted in long jail terms and fines for them (Meneses, 2019; Plataforma Macau, 2018). Similarly, the CPIB investigated the bribery 
complaints against Teh and recommended his prosecution to the Attorney-General but he committed suicide before he could be prosecuted (Parliament of Singapore, 1987, pp. 29-30). As Yeo was a CPIB senior officer, the CAD investigated his offences to avoid a conflict of interest and he was found guilty and imprisoned for 10 years (Quah, 2015, pp. 77, 83-84).

Corruption scandals in Asian countries

\section{Lessons for combating corruption in other countries}

The first and most important lesson arising from the preceding analysis is that a government's response to a corruption scandal is a reflection not only of its political will to fighting corruption but also of the perceived extent of public sector corruption in the country. As Prime Minister Najib was himself implicated in the $1 \mathrm{MDB}$ scandal it is not surprising that he covered up his misconduct by removing some ministers, the Attorney-General and other officials to stop them from exposing his corrupt behaviour. Najib also hindered the investigations of the 1MDB scandal by the National Audit Department and MACC by directing his officials to withhold documents and computer files. The situation changed, however, when the Pakatan Harapan government assumed office after winning the May 2018 general election and ordered Najib's arrest on 3 July and his corruption trial began in April 2019.

In Japan, the bureaucrats in the Ministries of Finance and Education reacted to the two sontaku scandals by covering up the involvement of Prime Minister Abe and his wife in the case of Kagoike's application and Abe's intervention in expediting his close friend Kake's application. Apart from the resignations of Sagawa and Maekawa, no other official was punished for altering documents and their role in concealing the two scandals. The behaviour of the Japanese bureaucrats is not surprising as Haynes (2000, pp. 101-103) has criticised the Japanese system for not engendering "responsibility, accountability, and transparency" because its "sullied mandarins" do not take "the flak for their shortcomings" as words like "accountability," "culpability" and "humility" are not in "their collective lexicons." The Japanese government did not punish the officials responsible for altering public documents to conceal the involvement of Prime Minister Abe and his wife in the two sontaku scandals. The Public Records and Archives Management Act implemented in 2011 required the government to preserve public documents as an intellectual resource for independent use by citizens. However, it did not prevent the Ministry of Finance bureaucrats from altering the documents in the Moritomo Gakuen scandal because there was no incentive for them to follow the rules.

The lack of transparency and accountability of the Japanese bureaucrats is not surprising and reflects the government's weak political will in changing the status quo that favours the structural corruption of the politicians, bureaucrats and business persons. Japan has still not ratified the United Nations Convention against Corruption (UNCAC) after signing it on 9 December 2003 because Articles 6 and 36 require it to establish an ACA to combat corruption. Japan's 16-year delay in ratifying the UNCAC reflects its government's reluctance to replace the ineffective and inadequately staffed Special Investigation Departments in Tokyo, Osaka and Nagoya with an ACA. This explains why Japan does not have an ACA to curb corruption unlike the other five countries. Consequently, it is also not surprising that corruption scandals abound in Japan with 52 corruption scandals occurring from 1948 to 2008 (Quah, 2011, p. 44).

When the BNPP scandal was exposed by the US media and the NBN-ZTE scandal was revealed by a local journalist, there was no attempt by the officials in the Philippines to conceal the fact that both procurement contracts were approved by the two presidents by brokers instead of competitive public bidding and following the proper procedures. Disini was found guilty after 24 years of investigation and ordered to return the commission from the BNPP deal but he died in June 2014 without returning the money. However, there was insufficient evidence to prosecute President Marcos, and Abalos and Mike Arroyo for 
PAP

23,1

receiving commissions for brokering the NBN-ZTE deal. Batalla has attributed the poor conviction rate of the offenders to the improper handling of evidence by the PCGG and the OMB's incompetence and mistakes made in investigating the two scandals. The OMB and PCGG, which are Type B ACAs performing both anti-corruption and other functions, are ineffective because they are "paper tigers" with poor reputations and limited personnel, powers and resources (Quah, 2017, pp. 58-60).

Prime Minister Modi's popularity and the BJP's victory in the 2014 general election in India enabled him to decide unilaterally without consulting parliament on the revised terms of the Rafale deal in April 2015. Similarly, the BJP's victory in the 2019 general election with an increased majority resulted in the revocation of Article 370 by Modi to fulfil the BJP's electoral promise and vested interests without consulting parliament or the population in J\&K. The situation in India is unlikely to change for the foreseeable future in view of the inability of the weak opposition political parties to challenge effectively any future controversial policies introduced by Modi's government.

The second lesson is that governments must address the causes of corruption in general and corruption scandals in particular if they are concerned with minimising corruption and preventing the recurrence of corruption scandals in their countries. Corruption is widespread in many Asian countries because many corrupt political leaders, senior civil servants, business persons and citizens resist and subvert the implementation of comprehensive anticorruption reforms to address the causes of corruption to protect their vested interests (Quah, 2017, p. 68). The 1MDB scandal clearly illustrates Prime Minister Najib's blatant use of 1MDB funds to feather his own kleptocratic interests.

A recent evaluation concludes that anti-corruption efforts in Malaysia are "rife-ridden" and ineffective because of "the lack of political will, failure of proposed initiative[s] to address [the] causes of corruption, duplication and a lack of public support for corruption prevention" (Kapeli and Mohamed, 2019, p. 554). Consequently, Malaysia's Corruption Perceptions Index (CPI) score decreased from 52 in 2014 to 47 in 2018. Jones has attributed the 1MDB scandal to Najib's lack of political will to curb corruption, which is reflected in the 1MDB's defective system of governance, his interference in the MACC's and National Audit Department's investigations, and the failure to enforce the FATF's preventive money-laundering regulations. The MACC is a Type A ACA responsible for performing only anti-corruption functions but its effectiveness as an independent watchdog has been severely hindered by political interference from Prime Minister Najib. As the Pakatan Harapan government is preoccupied with Najib's on-going corruption trial and attempts to recover the stolen $1 \mathrm{MDB}$ funds, it has not initiated appropriate reforms to address the causes of the 1MDB scandal and the widespread corruption in Malaysia yet. Nevertheless, the 2018 electoral defeat of Najib's government and its replacement by the Pakatan Harapan government is reflected in Malaysia's improved CPI score of 53 in 2019 (Transparency International, 2020).

The Government Procurement Reform Act of 2003 in the Philippines requires all government projects to undergo public bidding but the NBN-ZTE deal was approved as an exception because it was a government-to-government agreement. Batalla contends that grand corruption scandals will persist in the Philippines because of the strong incentives for corrupt behaviour and the justice system's failure to bring closure to past corruption scandals as reflected in the low risk of punishment for corruption offenders. President Estrada was found guilty in September 2007 of receiving payoffs and kickbacks and sentenced to 40 years' imprisonment. However, he was pardoned six weeks after his conviction by President Arroyo against the advice of anti-corruption advocates and state prosecutors (Quah, 2011, p. 148).

Even though Macau's CAC investigated and prosecuted Ao and Ho for their multiple offences, Lo attributes Ao's scandal to the absence of effective auditing which enabled him to misbehave with impunity without checks by his superiors or subordinates. However, the reforms introduced by the Macau government after Ao's scandal were moderate and 
focussed only on institutional checks on the Secretary of Public Works and Transport at the level of his immediate colleagues, subordinates and appointed citizens without addressing his procedural relations with the Financial Secretary, Chief Secretary and Chief Executive. Similarly, even though the absence of regular and rigorous auditing in the ProsecutorGeneral's Office contributed to Ho's multiple offences during 1999-2014, the Macau government did not strengthen the auditing process to prevent a recurrence of his offences.

Singapore's response to the Teh and Yeo scandals illustrates its government's zerotolerance policy towards corruption and explains why it is perceived as the least corrupt Asian country on Transparency International's CPI from 1995 to 2019. Unlike Najib's government which covered up the $1 \mathrm{MDB}$ scandal or the Japanese bureaucrats who attempted to conceal Prime Minister Abe's involvement in the sontaku scandals, the People's Action Party (PAP) government in Singapore did not conceal the two scandals and investigated those persons responsible instead and punished Yeo for his offences but Teh committed suicide after being investigated by the CPIB.

The PAP government has also analysed the causes of the two scandals and introduced appropriate reforms to prevent their recurrence. As the Prevention of Corruption Act did not provide for the confiscation of the estate of an offender if he had obtained his benefits from corruption, an important consequence of Teh's scandal is the introduction of new legislation to plug this loophole. As Yeo was a gambling addict, he exploited the CPIB's weak internal controls and used the CPIB's funds to visit the two local casinos to satisfy his addiction. The Independent Review Panel (IRP), which was appointed in July 2013 by the Prime Minister to investigate the causes of Yeo's misconduct, concluded that supervisory lapses enabled Yeo to commit his offences and recommended reforms to strengthen the CPIB's financial procedures and audit system. Two CPIB Directors were given letters of warning by the Prime Minister's Office for their failure to supervise Yeo during their terms of office from July 2005 to September 2013. Prime Minister Lee Hsien Loong appointed a new CPIB Director on 1 October 2013 to implement the IRP's recommendations. Furthermore, the Public Service Division announced that from 1 October 2013 all civil servants in Singapore are required to declare their visits to the local casinos to prevent a recurrence of Yeo's offences. In January 2014, the Ministry of Finance formulated a government procurement code of ethics and professional conduct standards for procurement officers and introduced a new reporting system to minimise the occurrence of the procurement lapses in government agencies reported by the Auditor-General's Office in 2013.

The final lesson is the recognition that no country, including Denmark and New Zealand, which share the top position amongst 180 countries on the $2019 \mathrm{CPI}$, is immune from corruption scandals (Transparency International, 2020). In Denmark, there were two scandals in 2018: the money-laundering scandal at the Estonian branch of the Danske Bank and the embezzlement scandal at the Ministry for Children and Social Affairs' administrative department (The Local, 2019). A content analysis of two newspapers found 622 New Zealand corruption stories during 2000-2016 (Barrett and Zirker, 2016, p. 229).

Combating corruption is a difficult task that requires sustained commitment by a government and its allocation of adequate personnel, budget, legal powers and operational autonomy to the ACA to enable it to enforce the anti-corruption laws impartially, regardless of the position, status or political affiliation of the offenders. Indeed, combating corruption in Asian countries is a continuous work in progress because, apart from the resources and expertise required by the Type A ACAs, the implementation of anti-corruption laws will be strongly resisted by kleptocratic and powerful corrupt individuals with vested interests to circumvent these laws to avoid arrest and conviction for their offences (Quah, 2017, p. 79).

As corruption scandals cannot be prevented, what those governments that are concerned with minimising corruption in their countries should do is to avoid covering up a scandal when it occurs and direct their ACAs to investigate impartially the scandal to establish the
Corruption

scandals in

Asian

countries 
PAP

23,1

guilt of the offenders and punish them according to the law if they are found guilty. These governments should also identify the causes of the scandal so that appropriate reforms can be introduced to address these causes. Needless to say, only those governments with a strong dose of political will to combat corruption will adopt this recommended approach for handling corruption scandals. In this context, it is instructive to quote Prime Minister Lee Hsien Loong's justification of the Singapore government's tough stand against corruption:

Anyone who breaks the rules will be caught and punished - no cover-ups, no matter how senior the officer or how embarrassing it may be. It is far better to suffer the embarrassment and keep the system clean, than to pretend that nothing went wrong and let the rot spread (Lee, 2012, p. A23).

In the final analysis, when a government decides to cover-up a scandal instead of investigating it, punishing the guilty offenders and initiating reforms to address its causes, the dire consequences are predictable: corruption scandals, like cancer, will proliferate because corrupt individuals and organisations in the country can continue to misbehave with impunity and encourage other citizens to follow suit. Covering up corruption scandals will not make them disappear but guarantee their recurrence.

\section{References}

Aquino, B.A. (1999), Politics of Plunder: The Philippines under Marcos, 2nd ed., Great Books Trading and National College of Public Administration, University of the Philippines, Quezon City.

Barrett, P. and Zirker, D. (2016), "Corruption scandals, scandals clusters and contemporary politics in New Zealand”, International Social Science Journal, Vol. 66 No. 4, pp. 229-240.

BBCNews (2019), "Article 370: what happened with Kashmir and why it matters", 6 August, available at: https://www.bbc.com/news/world-asia-india-49234708 (accessed 10 December 2019).

Beaver, W. (1994), "Nuclear nightmares in the Philippines", Journal of Business Ethics, Vol. 13 No. 4, pp. 271-279.

Brown, C.R. (2018), The Sarawak Report: The Inside Story of the 1MDB Exposé, Gerakbudaya Enterprise, Petaling Jaya.

Butterfield, P. (1978), "Marcos, facing criticism, may end $\$ 1$ billion Westinghouse contract", New York Times , 14 January.

Carlson, M.M. (2017), "Policy failure scandals as political scandals in Japan", Asian Survey, Vol. 57 No. 5, pp. 933-955.

Carlson, M.M. and Reed, S.R. (2018a), Political Corruption and Scandals in Japan, Cornell University Press, Ithaca, NY.

Carlson, M.M. and Reed, S.R. (2018b), "Scandals during the Abe administrations," in Pekkanen, R.J., Reed, S.R., Scheiner, E. and Smith, D.M. (Eds), Japan Decides 2017: The Japanese General Election, Palgrave, Basingstoke, pp. 109-126.

Case, W. (2017), "Stress testing leadership in Malaysia: the 1MDB scandal and Najib Tun Razak", Pacific Review, Vol. 30 No. 5, pp. 633-654.

Chong, E. (2014), "Anti-graft officer gets 10 yrs jail”, Straits Times, 21 February, p. A1.

Colmey, J. and Liebold, D. (1999), "The family firm”, Time, 24 May, pp. 15-29.

Coronel, S.S. (Ed.) (2000), Investigating Estrada: Millions, Mansions and Mistresses, Philippine Center for Investigative Journalism, Quezon City.

Dixon, K. (1977), “Japan’s Lockheed scandal: 'structural corruption”, Pacific Community, Vol. 8 No. 1, pp. 340-362.

Downey, B. (1975), “The Godber affair”, Hong Kong Law Journal, Vol. 5, pp. 129-133.

Financial Action Task Force (FATF) (2019), "What do we do", available at: https://www.fatf-gafi.org/ about/whatwedo/ (accessed 17 December 2019). 
Gabriel, C. (2018), "Malaysia's missing billions”, Journal of Democracy, Vol. 29 No. 1, pp. 69-75.

Garnault, J. (2012), The Rise and Fall of the House of Bo, Penguin Group Australia, Melbourne.

Glynn, P., Kobrin, S.J. and Naim, M. (1997), “The globalization of corruption”, in Elliott, K.A. (Ed.), Corruption and the Global Economy, Chapter 1, Institute for International Economics, Washington, DC, pp. 7-27.

Gunasegaram, P. (2018), 1MDB: The Scandal that Brought Down a Government, Strategic Information and Research Development Centre, Petaling Jaya.

Corruption

scandals in

Asian

countries

Hassan, H. (2019), "Najib's trial for 7 charges adjourned after short hearing”, Straits Times, 4 April, p. A9.

Haynes, D. (2000), Japan's Big Bang: The Deregulation and Revitalization of the Japanese Economy, Tuttle Publishing, Boston, MA.

Hilotin, J. (2019), “India's Rafale deal: what the controversy is all about”, Gulf News, 12 February.

Ho, P. and Huang, W. (2013), A Death in the Lucky Hotel Murder, Money, and an Epic Power Struggle in China, Public Affairs, New York, NY.

Japan Times (2020), "Moritomo Gakuen couple in Abe cronyism scandal found guilty of fraud", 19 February.

Kan'ichi, F. (1976), "Lockheed incident: parliamentary democracy and political corruption”, Japan Interpreter, Vol. 11 No. 2, pp. 159-166.

Kapeli, N.S. and Mohamed, N. (2019), "Battling corruption in Malaysia: what can be learned?", Journal of Financial Crime, Vol. 26 No. 2, pp. 549-555.

Kearns, I. (1990), "The Recruit scandal and corruption in Japanese political life", Corruption and Reform, Vol. 5 No. 1, pp. 63-70.

King, A. (1986), "Sex, money, and power", in Hodder-Williams, R. and Ceaser, J. (Eds), Politics in Britain and the United States: Comparative Perspectives, Chapter 7, Duke University Press, Durham, NC, pp. 173-202.

Kitazawa, M. (1976), “The Lockheed incident and Japanese culture”, Japan Interpreter, Vol. 11 No. 2, pp. 219-223.

Latiff, R. and Ananthalakshmi, A. (2018), "The cover-up: Malaysian officials reveal just how much $1 \mathrm{MDB}$ probe was obstructed", Reuters, 4 July, London.

Lee, H.L. (2012), "Incorruptibility ingrained in S'porean psyche”, Straits Times, 19 September, p. A23.

Lee, F.L.F. (2018), "Political scandals under repressive authoritarianism: the case of the Bo Xilai trial in China", International Journal of Communication, Vol. 12, pp. 3048-3066.

Lethbridge, H.J. (1985), Hard Graft in Hong Kong: Scandal, Corruption, the ICAC, Oxford University Press, Hong Kong.

Lim, K.S. (1986), BMF: Scandal of Scandals, Democratic Action Party, Petaling Jaya.

Llanto, J.F. and Chavez, L. (2008), “Timeline: exposing the ZTE overprice”, ABS-CBNNews, 24 November, available at: https://news.abs-cbn.com/nation/11/24/08/timeline-exposing-zte-overprice (accessed 5 December 2019).

Lowi, T.J. (1988), "Foreword", in Markovits, A.S. and Silverstein, M. (Eds), The Politics of Scandal: Power and Process in Liberal Democracies, Holmes and Meier Publishers, New York, NY, pp. vii-xii.

MacDougall, T. (1988), "The Lockheed scandal and the high costs of politics in Japan”, in Markovits, A.S. and Silverstein, M. (Eds), The Politics of Scandal: Power and Process in Liberal Democracies, Chapter 8, Holmes and Meier Publishers, New York, NY, pp. 193-229.

Mathews, J. and Wideman, B. (1977), "Martial law benefits Marcos' friends", Washington Post, 19 December.

Mathews, J. and Wideman, B. (1978), "Marcos orders seizure of wealthy friends' companies", Washington Post, 18 January. 
PAP

23,1

Mendoza, R.U., Paras, Y.G. and Bertulfo, D.J. (2016), The Bataan Nuclear Power Plant in the Philippines: Lessons from a White Elephant Project, Working Paper 16-001, Ateneo School of Government, Ateneo de Manila University, Quezon City.

Meneses, J.P. (2019), “2007 - Ao man long”, Macau Business, 19 May.

Meng, Q. (2013), Corruption in Transitional China: A 33-Year Study, Wolf Legal Publishers, Oisterwijk.

Milne, R.S. (1987), "Levels of corruption in Malaysia: a comment on the case of Bumiputra Malaysia Finance", Asian Journal of Public Administration, Vol. 19 No. 1, pp. 56-73.

Mitchell, R.H. (2002), Justice in Japan: The Notorious Teiin Scandal, University of Hawaili Press, Honolulu, HI.

Osaki, T. (2017), "Maekawa details Kake scandal allegations in special Diet hearing", Japan Times, 10 July.

Oza, B.M. (1997), Bofors: The Ambassador's Evidence, Konark Publishers, Delhi.

Parakh, P.C. (2014), Crusader or Conspirator? Coalgate and Other Truths, Manas Publications, New Delhi.

Parliament of Singapore (1987), Report of the Commission of Inquiry on Investigations Concerning the Late Mr Teh Cheang Wan, Cmd. 18 of 1987, Singapore National Printers, Singapore.

Pesqué-Cela, V. (2018), "Corruption in China”, in Warf, B. (Ed.), Handbook on the Geographies of Corruption, Chapter 19, Edward Elgar, Cheltenham, pp. 313-330.

Plataforma Macau (2018), “The Ho Chio meng case”, 8 August, available at: https://www. plataformamedia.com/en-uk/news/society/the-ho-chio-meng-case-9540506.html (accessed 3 December 2019).

Pope, J. (2000), Confronting Corruption: The Elements of a National Integrity System, Transparency International, Berlin.

Quah, J.S.T. (2011), Curbing Corruption in Asian Countries: An Impossible Dream?, Emerald Group Publishing, Bingley.

Quah, J.S.T. (2013), Minimizing Corruption in China: Is this an Impossible Dream?, Carey School of Law, University of Maryland, Baltimore, MD.

Quah, J.S.T. (2015), “Singapore's Corrupt Practices Investigation Bureau: four suggestions for enhancing its effectiveness", Asian Education and Development Studies, Vol. 4 No. 1, pp. 76-100.

Quah, J.S.T. (2017), Combating Asian Corruption: Enhancing the Effectiveness of Anti-corruption Agencies, Carey School of Law, University of Maryland, Baltimore, MD.

Ramesh, R. (2016), "1MDB: the inside story of the world's biggest financial scandal”, The Guardian, 28 July.

Republic of the Philippines Sandiganbayan (2016), SB-11-CRM-0467, People of the Philippines v. Gloria Macapagal-Arroyo et al., Quezon City, available at: sb.judiciary.gov.ph/recentdecision. php?docutype $=$ RESOLUTIONS\&year $=2016($ accessed 17 March 2020).

Republic of the Philippines Senate (2009), Committee on Accountability of Public Officers and Investigations, Committee Report No. 743, "NBN-ZTE Executive Summary," Pasay, available at: https://www.senate.gov.ph/lisdata/1293411633!.pdf (accessed 17 March 2020).

Scott, I. (2014), "Political scandals and the accountability of the Chief Executive in Hong Kong", Asian Survey, Vol. 54 No. 5, pp. 966-986.

Sim, W. (2017), "Cronyism scandal: Abe denies any wrongdoing”, Straits Times, 25 July.

Sim, W. (2018), "No orders came from Japan PM Shinzo Abe to alter Moritomo documents: key witness", Straits Times, 27 March.

Sim, W. (2020), "Old suicide note, new lawsuit put Abe on the spot again”, Sunday Times, 22 March, p. A16. 
Soble, J. (2017), "Bigotry and fraud scandal at kindergarten linked to Japan's First Lady", New York Times, 24 February, p. 6.

Star Online (2018), "Special task formed to look into 1MDB", 21 May, Petaling Jaya, available at: https://www.thestar.com.my/news/nation/2018/05/21/special-task-force-formed-to-look-into1mdb/ (accessed 15 December 2019).

Supreme Court Observer (2019), "Rafale fighter jet deal: Manohar Lal Sharma v. Narendra Damodardas Modi”, Case-Number: WP (Crl.) 225/2018; RP (Crl.) 46/2019, available at: https:// www.scobserver.in/court-case/undefined (accessed 10 December 2019).

Teh, Y.K. (2018), From BMF to 1MDB: A Criminological and Sociological Discussion, Strategic Information and Research Development Centre, Petaling Jaya.

The Local (2019), "Denmark still considered the world's least corrupt country, despite 2018 scandals", 29 January, available at: https:/www.thelocal.dk/20190129/denmark-still- considered-worldsleast-corrupt-country-despite-2018-scandals (accessed 19 January 2020).

Thompson, J.B. (2000), Political Scandal: Power and Visibility in the Media Age, Polity Press, Cambridge.

Transparency International (2004), Global Corruption Report 2004, Pluto Press, London.

Transparency International (2020), Corruption Perceptions Index 2019, Transparency International, Berlin.

Trehan, M. (2009), Tehelka as Metaphor: Prism me a Lie, tell me a truth, Roli Books, New Delhi.

Weiss, M.I. (2019), "Money, malfeasance, and a Malaysian election”, in Hutchinson, F.E. and Lee, H.A. (Eds), The Defeat of Barisan Nasional: Missed Signs or Late Surge? Chapter 6, ISEAS Publishing, Singapore, pp. 131-150.

West, M.D. (2006), Secrets, Sex, and Spectacle: The Rules of Scandal in Japan and the United States, University of Chicago Press, Chicago, IL.

Wright, T. and Hope, B. (2019), Billion Dollar Whale: The Man Who Fooled Wall Street, Hollywood, and the World, Hachette Books, New York, NY.

Yayama, T. (1990), “The Recruit scandal: learning from the causes of corruption”, Journal of Japanese Studies, Vol. 16 No. 1, pp. 93-114.

Yoshida, R. (2018), "Breaking down the Kake Gakuen scandal: who's lying, Abe or his political opponents?", Japan Times, 1 June.

Zhu, J. (2017), "Corruption networks in China: an institutional analysis", in Gong, T. and Scott, I. (Eds), Routledge Handbook of Corruption in Asia, Chapter 3, Routledge, London, pp. 27-41.

\begin{abstract}
About the author
Jon S.T. Quah is a retired Professor of Political Science at the National University of Singapore and an anti-corruption consultant based in Singapore. He has conducted research on corruption in Asian countries since 1977 and his recent books include: Combating Asian Corruption: Enhancing the Effectiveness of Anti-Corruption Agencies (2017); Hunting the Corrupt "Tigers" and "Flies" in China (2015); Minimizing Corruption in China (2013); Curbing Corruption in Asian Countries: An Impossible Dream? $(2011,2013)$ and Taiwan's Anti-Corruption Strategy (2010). Jon S.T. Quah can be contacted at: jonstquah@gmail.com
\end{abstract}

For instructions on how to order reprints of this article, please visit our website:

www.emeraldgrouppublishing.com/licensing/reprints.htm

Or contact us for further details: permissions@emeraldinsight.com 